\title{
The Interplay of Digital Transformation and Collaborative Innovation on Supply Chain Ambidexterity
}

\author{
Sara Abdalla, Koichi Nakagawa
}

\begin{abstract}
"While opposition in itself might achieve progress, disorder and confusion might also result. Harmony might achieve stability, but without great progress and prosperity. Opposition needs to be aligned with harmony. ”
\end{abstract}

\author{
Kōnosuke Matsushita \\ Founder of Panasonic Corporation
}

\begin{abstract}
This study aims at investigating the impact of digital transformation on the efficiency and adaptability of a supply chain (SC). It also identifies the role of collaborative innovation as a catalyst in these relationships. Survey data from Japanese manufacturing companies was examined using hierarchical multiple regression analysis to test the study's hypotheses. According to the results, collaborative innovation with SC members, that is, suppliers and customers, strengthens the impact of digital transformation on adaptability, but not on efficiency. In contrast, collaborative innovation with market participants, such as competitors and partners, reinforces the positive relationship between digital transformation and efficiency, with no evidence supporting its effect on the innovation-adaptability relationship. These findings encourage firms to widen the scope of their collaborative innovation activities to include different types of partners. For firms with limited abilities to conduct such complex collaboration projects, the findings can assist managers in making well-informed decisions to include partners that accommodate prioritized organizational goals.
\end{abstract}

\section{Introduction}

Digital technologies have a profound impact on consumer behavior (Chanias, 2017) and the competitive landscape (Vial, 2019). They create growth opportunities as well as existential threats to companies. By providing the means by which firms can reconfigure their product/service mix, digital technologies allow for the creation of new offerings (Yoo et al., 2010). These technologies can change products and services and create new business models (Loebbecke \& Picot, 2015). Additionally, they impact the ways consumers interact with companies and with each other (Karagiannaki et al., 2017).

Several studies (for example, Günther et al., 2017; Svahn et al., 2017) have established positive relationships between the usage of big data, the internet of things
(IoT), analytics, and artificial intelligence, and the increased efficiency and adaptability of firms. Thus, balancing traditionally conflicting targets, a vital capability involving the "ambidexterity" of a firm (Gibson \& Birkinshaw, 2004), can be enabled by the use of digital technologies (Svahn et al., 2017). Digital transformation, the "transformations in organizations that are driven by new enabling [information technology] IT/ [information systems] IS solutions and trends" (Heilig et al., 2017), is therefore considered as key for firms to survive, since it drives operational performance and enables significant business improvements (Hess et al., 2016; Agrawal et al., 2019).

Despite acknowledged advantages, the mere implementation of digital technologies is not sufficient (Kane, 2014). In a world where talent and valuable knowhow are widely distributed, organizations cannot pursue 


\section{The Interplay of Digital Transformation and Collaborative Innovation on Supply Chain Ambidexterity Sara Abdalla, Koichi Nakagawa}

innovation independently, no matter how large or capable they are (Burchardt \& Maisch, 2019). Firms now realize the crucial necessity of exploring external sources of technology and ideas to augment in-house R\&D (Gassmann, 2006). Thus, creating business value requires firms to open up their innovation processes and develop capabilities to combine internally and externally developed technologies (Chesbrough, 2003).

Firms collaborate with external actors, such as suppliers, customers, competitors, and research organizations, for several purposes. These may include improving distribution, broadening the product assortment, and increasing manufacturing flexibility (Najafi-Tavani et al., 2018). A firm's innovation capability can also be advanced by such collaboration. This is due to improved knowledge sharing and market knowledge acquisition that results in the expansion of a company's knowledge base (Zhou \& Li, 2012). By inviting other parties to participate in the innovation process, valuable knowledge and experience can be shared among different actor networks, which enable companies to reduce time-to-market and cost, as well as improve development quality (Laursen \& Salter, 2006; Swink, 2006).

Building on the resource-based view, dynamic capabilities theory, and organizational ambidexterity literature, we investigate how external collaboration in innovation can impact the relationship between using digital technologies and improved SC performance in terms of efficiency and adaptability. We suggest that the benefits of using digital technologies to manage a SC and improve its performance could be limited without incorporating structural changes of a company's network to include real collaborative innovation activities that transcends its boundaries. We believe this issue is significantly important since the trend towards co-innovation and collaboration across organizational boundaries is intensifying. We thus explore the moderating role of collaborative innovation in this paper using two types of partners: SC members, that is, suppliers and customers, and other participants in the market, such as logistics service providers, consultants, or even competitors.

In the following sections, we first review the relevant literature and touch on the theoretical underpinnings and rationale for the proposed hypotheses. Next, we present the methodology used in the study, followed by an analysis of the results. We conclude with a discussion and reflection on the practical implications of the research findings.

\section{Theoretical Background and Hypothesis Development}

\section{Ambidexterity in supply chain management}

In the field of supply chain management (SCM), organizational ambidexterity has emerged as an appropriate theoretical perspective for explaining innovation and performance improvement (Lee \& Rha, 2016). Ambidexterity, that is, the simultaneous utilization of exploitation and exploration (Gibson \& Birkinshaw, 2004), is a controversial topic in the organizational theory and strategic management literature. From a SC perspective, exploration refers to the continuous search for knowledge and solutions that address market changes (Abernathy \& Clark, 1993), allowing for enhanced adaptability. In contrast, exploitation leverages current SC capabilities in search of efficiency, and improves them to reach lower cost and greater reliability (Barnes et al., 2004). A SC is deemed "ambidextrous" when it has the "ability to maintain daily operations excellence while looking for constant innovation and the ability to keep balance" (Castorena \& Monroy, 2020). Such a capability as ambidexterity enables firms to mitigate the negative impact of SC disruptions and enhance business performance (Lee \& Rha, 2016).

However, exploration and exploitation activities compete for organization's scare resources. Thus, some scholars view them as fundamentally incompatible (Hannan \& Freeman, 1977; Ancona et al., 2001) while others believe that reconciliation is possible due to the complementary, rather than competing nature of these capabilities (Schulze et al., 2008). Since both exploration and exploitation are vital for firms' survival and competitive advantage, two mechanisms, structural and contextual, have been developed to achieve the desired ambidexterity. Structural ambidexterity calls for creating separate organizational structures to deal with conflicting demands on different units (Duncan, 1976; Birkinshaw \& Gibson, 2004). This approach is promoted by scholars who support the incompatibility view of exploration and exploitation as it guarantees that each division or unit pursues their own direction of need without pressure to attend to the other direction. In contextual ambidexterity, rather than creating separate divisions, the activities of exploration and exploitation are viewed as complementary and are balanced within a single division structure (O'Reilly III \& Tushman, 2013).

\section{The impact of digital transformation on the SC's ambidexterity}

The change introduced by technology advancements brings new opportunities, as well as challenges, for most 


\section{The Interplay of Digital Transformation and Collaborative Innovation on Supply Chain Ambidexterity Sara Abdalla, Koichi Nakagawa}

enterprises. The digitalization of the SC offers plenty of solutions to tackle these challenges and allow firms to seize opportunities in the changing market. Improved customer service, more integration with suppliers and partners, increased sales, and overall business development are some of the benefits expected when taking the strategic decision of digital transformation (Agrawal et al., 2019). As digital transformation is being actively discussed in recent literature, several definitions have emerged with essential differences relating to the types of technologies involved and the nature of the transformation (Horlacher et al., 2016; Andriole, 2017). We adopt the definition developed by (Vial, 2019) in viewing digital transformation as "a process that aims to improve an entity by triggering significant changes to its properties through combinations of information, computing, communication, and connectivity technologies" (Vial, 2019).

Firms can transform their traditional SC into agile, customer-driven, and demand-sensitive networks by applying emerging digital technologies (Büyüközkan \& Göçer, 2018). In this way, firms will be able to improve the visibility of their operations, leading to reduced costs and delivery times, and leveraged efficiency (Büyüközkan \& Göçer, 2018; Calatayud et al., 2019). Previous studies found that operational efficiency can be achieved through the use of digital technologies. For example, Pagani (2013) highlighted cost savings as a result of digital transformation. The optimization of business processes can also be achieved using IoT and analytics, which reduce slack resources and improve efficiency (Du et al., 2016; Gust et al., 2017).

An adaptable SC can be reshaped when necessary (Ketchen \& Hult, 2007). The use of digital technologies assists firms in this pursuit by sensing and responding rapidly to the shifts in the market since they increase customer proximity and enhance scanning for new consumer trends (Setia et al., 2013; Hansen \& Sia, 2015). The enhanced visibility and coordination generated by utilizing technologies such as advanced planning systems (Jonsson et al., 2007) and IT systems (Yoon et al., 2016) are vital for firms' ability to achieve adaptability, as it increases the firm's capacity for sensing and seizing opportunities in external environments. Thus, we consider digital transformation as an antecedent for improved SC performance in terms of efficiency and adaptability.

More precisely, we present the following hypothesis:

\author{
H1: Digital transformation positively impacts SCs' a) \\ efficiency and b) adaptability.
}

The interplay of digital transformation and collaborative innovation on SC efficiency and adaptability

Although the advantages of digital technologies are numerous, their mere implementation will produce little value (Kane, 2014). Based on the resource-based view, rival firms can easily duplicate investments in technologies, which impede the creation of sustained competitive advantage. Scholars and practitioners acknowledge the significance of internal, crossfunctional collaboration within a firm for successful digital transformation (Earley, 2014; Maedche, 2016). According to Chesbrough (2003), firms can also benefit from harvesting ideas from external parties, and from sharing their ideas, even with competitors. Thus, for digitization to succeed in creating and sustaining competitive advantage, firms must establish agile and collaborative organizational structures (Desmet et al., 2015; Selander \& Jarvenpaa, 2016). In this manner, companies can increase the potential to leverage a larger and more diverse pool of external sources in a rapid, cost-efficient, and flexible way (Gassmann \& Enkel, 2004), which improves business performance through increased efficient and effective use of external and internal resources (Monsef \& Ismail, 2012). The interplay of digitalization and collaborative innovation facilitates access to big data and the rapid processing of this data using novel tools such as artificial intelligence and machine learning (Burchardt \& Maisch, 2019).

Innovation is the result of an interactive process while collaborating with external parties is promoted as an innovation enhancer. In building cooperative networks, firms usually seek either synergies/complementariness, or growth and market power (Tether, 2002; Park et al., 2004). SC cooperation, that is, cooperation with the SC members such as suppliers and customers, is one of the most common complementary agreements (Miotti \& Sachwald, 2003). The purpose of these collaborations is to gain access to various types of assets owned by different parties by pooling or exchanging the assets (Arranz \& de Arroyabe, 2008). In cooperative agreements with rivals, where resources and problems are relatively similar, economies of scale, experience, and risk diversification are usually targeted to strengthen the competitive position by improving overall efficiency and resource management (Arranz \& de Arroyabe, 2008).

Despite their benefits, cooperative agreements are 


\section{The Interplay of Digital Transformation and Collaborative Innovation on Supply Chain Ambidexterity Sara Abdalla, Koichi Nakagawa}

usually associated with various challenges, including communication costs, a potential lock-in effect due to specific investments (Heide \& John, 1990), and unnecessary knowledge spill-overs (Oxley \& Sampson, 2004). Another challenge is choosing suitable partners, since engaging with different cooperative partners results in different innovation outcomes (Hyll \& Pippel, 2016). Several studies have investigated the impact of external sources of knowledge on innovation outcomes (Fritsch \& Lukas, 2001; Becker \& Dietz, 2004; Hyll \& Pippel, 2016). For example, Becker and Dietz (2004) found positive effects of engagement with customers and competitors as sources of knowledge on technological opportunities, while cooperation between suppliers yielded adverse effects. In their study, Hyll and Pippel (2016) found that cooperating with suppliers led to higher product and process innovation failure, while cooperating with competitors was associated with process innovation failure only. Cooperating with customers, however, was not linked to any innovation failure.

In line with the discussions of the previous studies, we thus propose the following hypotheses:

H2: Collaborative innovation with SC members strengthens the effect of digital transformation on a) efficiency and b) adaptability.

H3: Collaborative innovation with the market and industry members strengthens the effect of digital transformation on a) efficiency and b) adaptability.

The figure below (Figure 1) illustrates the proposed relationships in this study.

\section{Methodology}

\section{Sample and data collection}

Data for this research was collected via a survey instrument from a sample of Japanese manufacturing firms. Holding the world's third-largest number of patents (World Intellectual Property Indicators, 2019), Japan's business landscape is an innovation-supported environment accelerated by its firms' $R \& D$ capabilities and government regulatory reforms. The Japanese robotics and IoT markets have witnessed robust and continuous growth due to the government's promotion of Society 5.0, a super-smart society largely dependent on technology (Evolving Innovation, 2019). These characteristics qualify the Japanese business environment as suitable for this specific research topic.

We developed a survey instrument to collect data for this study. An English version of the questionnaire was developed first, then translated into Japanese language. In Japan, the postal service is widely used, and it is usually preferred over other types of communication, especially for business transactions. Japanese managers will probably respond better to post mails than e-mails. For this reason, we chose postal mail to contact respondents. We used an address database and random sampling technique to develop a list of 584 manufacturing firms located in the city of Osaka. Cover letters, including a link and $\mathrm{QR}$ code to the online questionnaire, were sent by mail to the firms. Three mails were returned due to wrong/invalid addresses, resulting in 581 sent by mail. Over a three-week waiting period, 46 valid questionnaires were filled, yielding around an $8 \%$ response rate. Analysis of the respondents' demographic information showed that

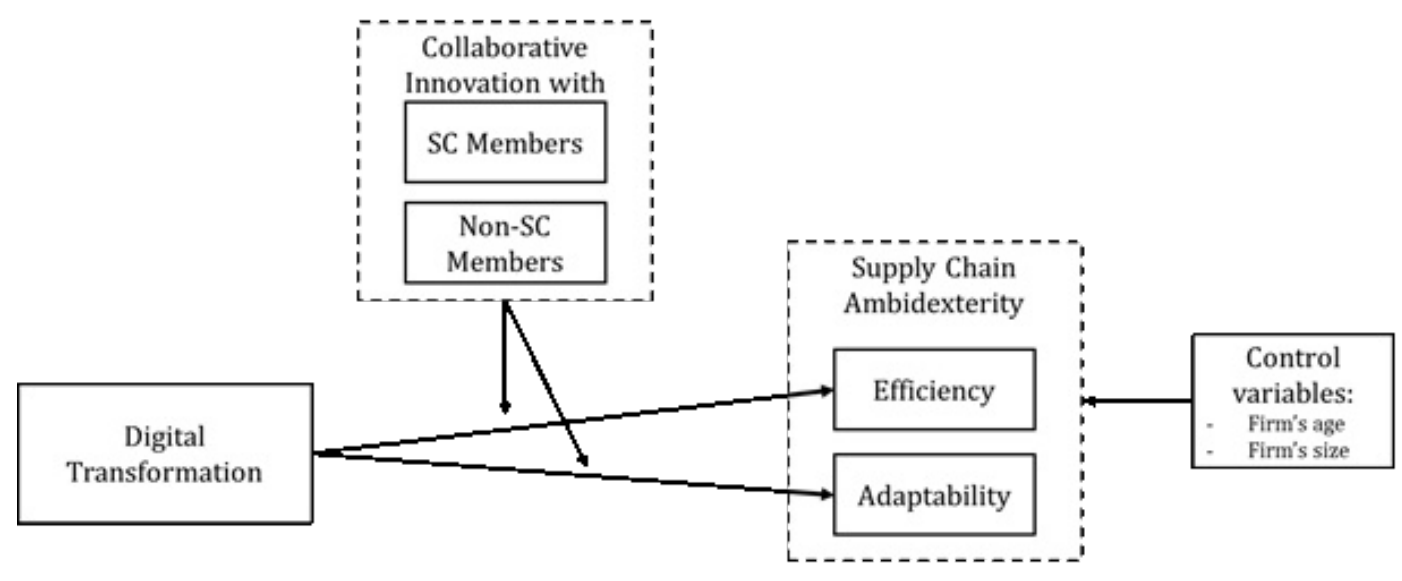

Figure 1. Research framework 


\section{The Interplay of Digital Transformation and Collaborative Innovation on Supply Chain Ambidexterity Sara Abdalla, Koichi Nakagawa}

$50 \%$ of the respondents belonged to the top management level, and $32 \%$ had over 10 years of experience. Most firms (76\%) were of medium size (100999 employees) and $85 \%$ of them were established in the 1970s. The firms belonged to various industries, with petroleum, chemical, and medical $(24 \%)$, as well as nonmetallic products $(17 \%)$, as the most frequent.

\section{Measures}

We used measures pre-validated in extant literature. All variables were measured based on 7-point Likert scales ( $1=$ strongly disagree/ much worse, $7=$ strongly agree/ much better). Digital transformation (DigTrans) was measured using four items adopted from Kim et al. (2006), Kwak et al. (2018), and Stentoft and Rajkumar (2018). The respondents were asked to indicate their agreement with statements reflecting their firms' usage of the most advanced enterprise resource planning (ERP) systems, other advanced IT systems, real-time tracking technologies, IoT, and artificial intelligence, over the past three years. SC Efficiency was measured using three items modified from Sezen (2008), who adopted them from Beamon (1999). The respondents were asked, based on personal judgment, to assess their firms' performance over the past three years in terms of the total cost of SC resources, costs associated with held inventory, and the SC's return on investments. SC adaptability was measured using three items adopted from $\mathrm{Pu}$ et al. (2020), who adopted them from Gibson and Birkinshaw (2004), and Im and Rai (2008). The respondents were asked, based on personal judgment, to assess and compare with their closest competitor(s), their firms' performance over the past three years in terms of the ability to adapt SC relationships, business priorities, and activities responding to different changes in the market and external environment. Collaborative innovation was measured using modified items from Stentoft and Rajkumar (2018). The respondents were asked to indicate their agreement with statements reflecting their company's level of engagement over the past three years in supply chain collaborative innovation (SCCI) and market/industry collaborative innovation (MICI). SCCI was defined as innovation with suppliers and customers, while MICI included consultants, logistics service providers, partners, and/or competitors as innovation partners. The two moderators, SCCI and MICI, were then transformed into dummy variables by dividing each into high (one standard deviation above the mean, coded as one) and low (one standard deviation below the mean, coded as zero) levels. Finally, we controlled for the companies' ages and sizes (measured by the number of employees). Table 1 presents descriptive statistics and correlations among the study variables.

\section{Scale reliability and validity}

The study constructs were assessed for their reliability, convergent validity, and discriminant validity. We used SmartPLS (Ringle et al., 2005) to run this part of the analysis. The indicator loadings ranged from 0.68 to 0.94 (all significant at the 0.05 significance level). The scores of Cronbach's alfa $(\alpha)$ and composite reliability (CR) were above the recommended level of 0.70 (Hair et al., 2019). The average variance extracted (AVE) scores exceeded the threshold of 0.50 (Hair et al., 2019). These results confirm the reliability and convergent validity of the constructs. The discriminant validity was assessed using the Heterotrait-Monotrait (HTMT) ratio of correlation (Henseler et al., 2015). All correlations were below the cut-off value of 0.90 , indicating acceptable discriminant validity.

The variance inflation factor (VIF) values were checked to detect possible collinearity among indicators and constructs. All values were below 5, indicating no presence of collinearity issues. Additionally, the occurrence of a VIF greater than 3.3 is proposed as an indication that a model may be contaminated by "common method bias" (Kock, 2015). None of the constructs' VIF scores in our study exceeded the threshold, indicating that the model is free of common method bias.

\section{Results}

We used RStudio ${ }^{\circledR}$ (RStudio Team, 2020) to run a hierarchical multiple regression analysis to test the study's hypotheses. In Table 2, we present the results of the analysis. Models 1 and 5 present the base models, including control variables only. For both models, no effects were found. In models 2 and 6 , we introduced the independent variable of "digital transformation". We found positive effects of digital transformation on efficiency $(\beta=0.269$ significant at $\mathrm{p}<0.01)$ and adaptability $(\beta=0.395$ significant at $\mathrm{p}<0.01)$, which predicted $30 \%$ and $12 \%$ (adjusted R2 of 0.301 and 0.120 ) of the variance in efficiency and adaptability, respectively. Thus, H1a and H1b were both supported.

To test the moderation hypotheses, we created dummy variables by splitting the moderators, SCCI and MICI, into high values (one standard deviation above the mean) and low values (one standard deviation below the mean). This procedure resulted in a reduction in the sample size because the scores at, and marginally around the mean were excluded. Models 3 and 7 present 


\section{The Interplay of Digital Transformation and Collaborative Innovation on Supply Chain Ambidexterity Sara Abdalla, Koichi Nakagawa}

Table 1. Descriptive statistics and correlations

\begin{tabular}{|c|c|c|c|c|c|c|c|c|}
\hline & Mean & $S D$ & 1 & 2 & 3 & 4 & 5 & 6 \\
\hline 1. Firm's size & 767 & 1262 & & & & & & \\
\hline 2. Firm's age & 71 & 31 & $0.36^{* *}$ & & & & & \\
\hline 3. Efficiency & 3.42 & 0.91 & 0.03 & 0.12 & & & & \\
\hline 4. Adaptability & 3.46 & 0.96 & -0.06 & 0.14 & $0.48^{* *}$ & & & \\
\hline 5. DigTrans & 3.30 & 1.40 & 0.12 & 0.16 & $0.42^{* *}$ & $0.57^{* *}$ & & \\
\hline 6. SCCI & 3.50 & 1.50 & 0.26 & 0.11 & $0.37^{* *}$ & $0.39 * *$ & $0.65^{* *}$ & \\
\hline 7. MICI & 3.80 & 1.70 & $0.40^{* *}$ & 0.16 & $0.35^{* *}$ & 0.28 & $0.58^{* *}$ & $0.80^{* *}$ \\
\hline
\end{tabular}

the results of the first set of moderation hypotheses (H2a and $\mathrm{H} 2 \mathrm{~b}$ ), which tested for the effects of collaborative innovation with suppliers and customers on a SC's efficiency and adaptability. As shown in model 3, no effect on efficiency was detected $(\beta=0.413$ nonsignificant at $\mathrm{p}<0.10$ ). Hence, $\mathrm{H} 2 \mathrm{a}$ was not supported. In model 7 , however, the moderation effect was significantly positive $(\beta=0.518$ significant at $\mathrm{p}<0.10$ ). This result means that collaborative innovation with suppliers and customers reinforces the impact of digital transformation on adaptability, providing support for $\mathrm{H} 2 \mathrm{~b}$.

Models 4 and 8 present the results of the combined effects of digital transformation and collaborative innovation with the market and industry members on efficiency and adaptability (H3a and $\mathrm{H} 3 \mathrm{~b}$ ). The results show a positive effect on a SC's efficiency $(\beta=0.714$ significant at $\mathrm{p}<0.05)$, while no evidence was found to support the effect on adaptability $(\beta=0.413$ nonsignificant at $\mathrm{p}<0.10$ ). Thus, only H3a was supported.

To better understand the moderation results, we plotted significant results in Figure 2 and Figure 3. Figure 2 illustrates the effect of digital transformation and collaborative innovation with suppliers and customers on SC adaptability. The figure shows that, for firms with high collaborative innovation levels, increased digital transformation leads to significantly higher adaptability than firms with low levels of collaborative innovation. The situation is reversed for firms with higher collaborative innovation levels with market and industry members. As shown in Figure 3, these firms exhibit higher efficiency as their digital transformation levels increase compared to firms that have low collaborative innovation levels with the market and industry members.

\section{Discussion}

To survive and remain competitive, companies must be simultaneously efficient and adaptive (Aghina et al., 2015). Extant literature supports the role of using digital technologies to achieve such ambidexterity through a combination of exploring digital innovation and exploiting existing resources (Raisch et al., 2009). By using digital technologies, organizations can alter their value creation processes and uncover new ways to create value in response to changes in the environment (Huang et al., 2017). However, digital technologies alone cannot sustain a competitive advantage and can fall short of achieving the required outcomes. To reinforce its effects, the implementation of digital technologies must be coupled with company changes in strategy, culture, and structure that emphasize the importance of utilizing internal and external knowledge sources.

Previous studies have confirmed the impact of digital transformation impact on several aspects of business performance, including operational efficiency (Pagani, 2013), innovativeness (Svahn et al., 2017), financial performance (Karimi \& Walter, 2015), and organizational ambidexterity (Li et al., 2018). This paper contributes to this stream of literature by providing empirical evidence of the role of digital transformation in reconciling the efficiency-adaptability trade-off and achieving ambidexterity in SCs. We further present an explanation of how companies can augment a single outcome, efficiency or adaptability, in conditions where their current resource availability does not allow for the simultaneous pursuit of both targets.

This study's findings have revealed that the interplay of digital transformation, external cooperation, and search of knowledge, that is, collaborative innovation, has varying impacts on SC efficiency and adaptability based 


\section{The Interplay of Digital Transformation and Collaborative Innovation on Supply Chain Ambidexterity Sara Abdalla, Koichi Nakagawa}

Table 2. Analysis results

\begin{tabular}{|c|c|c|c|c|c|c|c|c|}
\hline & \multicolumn{8}{|c|}{ Dependent variable: } \\
\hline & \multicolumn{4}{|c|}{ SC Efficiency } & \multicolumn{4}{|c|}{ SC Adaptability } \\
\hline & (1) & (2) & (3) & (4) & (5) & $(6)$ & (7) & (8) \\
\hline \multirow[t]{2}{*}{ Firm size } & -0.000 & -0.000 & -0.000 & -0.000 & -0.000 & -0.000 & -0.000 & -0.000 \\
\hline & $(0.000)$ & $(0.000)$ & $(0.000)$ & $(0.000)$ & $(0.000)$ & $(0.000)$ & $(0.000)$ & $(0.000)$ \\
\hline \multirow[t]{2}{*}{ Firm age } & 0.004 & 0.002 & 0.003 & 0.013 & 0.006 & 0.003 & $0.010^{* *}$ & 0.007 \\
\hline & $(0.005)$ & $(0.004)$ & $(0.004)$ & $(0.008)$ & $(0.005)$ & $(0.004)$ & $(0.005)$ & (0.009) \\
\hline \multirow[t]{2}{*}{ DigTrans } & & $0.269^{* * *}$ & -0.074 & -0.207 & & $0.395^{* * *}$ & 0.078 & 0.116 \\
\hline & & $(0.093)$ & $(0.200)$ & $(0.244)$ & & $(0.087)$ & $(0.211)$ & $(0.255)$ \\
\hline \multirow[t]{2}{*}{ SCCI } & & & -0.698 & & & & -1.541 & \\
\hline & & & $(0.923)$ & & & & $(0.973)$ & \\
\hline \multirow[t]{2}{*}{ DigTrans* SCCI } & & & 0.413 & & & & $0.518^{*}$ & \\
\hline & & & $(0.265)$ & & & & $(0.279)$ & \\
\hline \multirow[t]{2}{*}{ MICI } & & & & -1.525 & & & & -0.822 \\
\hline & & & & $(1.153)$ & & & & $(1.202)$ \\
\hline \multirow[t]{2}{*}{ DigTrans* MICl } & & & & $0.714^{* *}$ & & & & 0.337 \\
\hline & & & & $(0.319)$ & & & & $(0.333)$ \\
\hline \multirow[t]{2}{*}{ Constant } & $3.159^{* * *}$ & ${ }^{*} 2.403^{* * *}$ & $3.155^{* * *}$ & * $2.734^{* * *}$ & $3.128^{* * *}$ & * $2.017^{* * *}$ & $2.235^{* * *}$ & $2.474^{* * *}$ \\
\hline & $(0.343)$ & $(0.411)$ & $(0.513)$ & $(0.671)$ & $(0.356)$ & $(0.382)$ & $(0.541)$ & $(0.699)$ \\
\hline Observations & 46 & 46 & 28 & 23 & 46 & 46 & 28 & 23 \\
\hline $\mathrm{R}^{2}$ & 0.016 & 0.179 & 0.428 & 0.498 & 0.034 & 0.355 & 0.531 & 0.399 \\
\hline Adjusted $\mathrm{R}^{2}$ & -0.030 & 0.120 & 0.297 & 0.350 & -0.010 & 0.309 & 0.424 & 0.223 \\
\hline F Statistic & 0.347 & $3.054^{* *}$ & $3.287^{* *}$ & $3.373^{* *}$ & 0.767 & $7.709^{* * *}$ & $4.981^{* * *}$ & $2.261^{*}$ \\
\hline $\mathrm{df}$ & $2 ; 43$ & $3 ; 42$ & $5 ; 22$ & $5 ; 17$ & $2 ; 43$ & $3 ; 42$ & $5 ; 22$ & $5 ; 17$ \\
\hline
\end{tabular}

on the type of cooperation partners. Specifically, companies that coupled higher digital transformation and greater collaboration with their SC partners showed a significant increase in their SC adaptability compared to firms with low levels of either digital transformation or SC collaboration. This result confirms that collaborative innovation with SC members can augment and reinforce the positive impacts of digital transformation on SC adaptability.

Nevertheless, no evidence was found to support the hypothesis that combining digital transformation and SC cooperation can improve SC efficiency. This result can be explained in light of the resource-based view. According to this view, collaboration agreements that target cost reduction and economies of scale, or efficiency, must be based on pooling similar resources rather than complementary ones. Since the types of resources usually exchanged in SC cooperation are complementary in nature, an insignificant impact on SC efficiency is expected.
The combined effect of using digital technologies and collaborating with non-SC members, such as consultants and competitors, positively impacted SC efficiency in the companies we studied, with no effect on adaptability. As discussed above, this is due to the economies of scale resulting from pooling similar resources. Because rivals have similar problems and resources, however, it is unlikely that cooperative agreements between them will provide the required knowledge and insights needed to improve adaptability.

\section{Conclusions}

Collaborative innovation transforms business competition and cooperation (Lichtenthaler, 2008) by emphasizing the idea of widespread involvement and interdependence between actors at all levels (Lamming, 1993). According to the above discussion, firms can achieve SC ambidexterity through widening the scope of collaborative innovation by including different types of partners. In this way, firms would reap the benefits 


\section{The Interplay of Digital Transformation and Collaborative Innovation on Supply Chain Ambidexterity Sara Abdalla, Koichi Nakagawa}

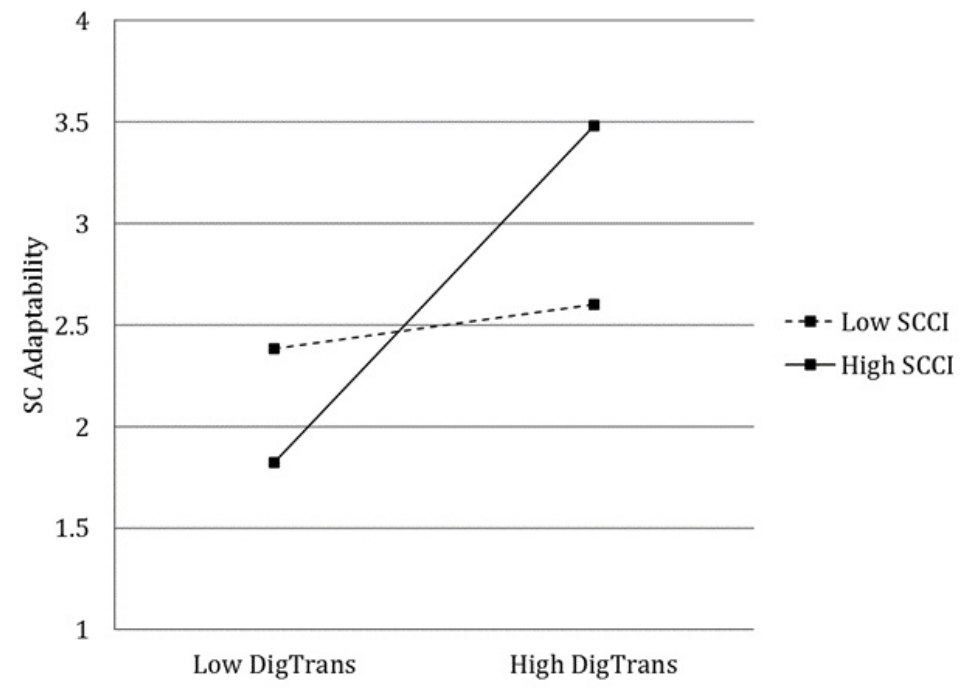

Figure 2. The effects of digital transformation and supply chain collaborative innovation on supply chain's adaptability.

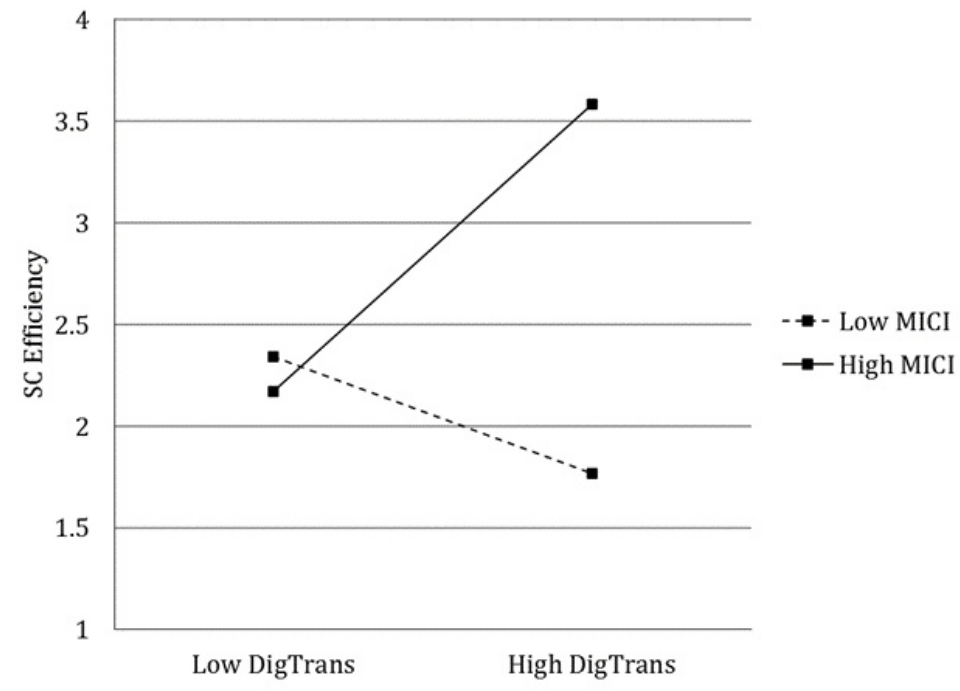

Figure 3. The effects of digital transformation and market/industry collaborative innovation on supply chain's efficiency.

associated with the inclusion of each type of partner. Although the management of several external cooperation projects with varying types of partners carries considerable challenges (Heide \& John, 1990), the expected outcomes represented in achieving SC ambidexterity would certainly remunerate. In instances where a company's resources are strictly limited in a way that complex coordination of projects is not possible, firms are advised to build cooperative networks with partners in alignment with the desired objective, using either complementary resources to facilitate adaptability or similar resources to boost efficiency.

\section{Suggestions for Future Research}

The findings of this study, as well as its limitations, can guide some future directions for research on this topic. Due to the bias inherent in self-reported perceptual data, we believe a longitudinal study would be necessary to provide a more in-depth and balanced investigation. Longitudinal studies are especially encouraged given the fact that the outcomes of collaborative innovation 


\section{The Interplay of Digital Transformation and Collaborative Innovation on Supply Chain Ambidexterity Sara Abdalla, Koichi Nakagawa}

activities may be assessed more accurately over the long term.

The Japanese business environment is known around the world for its uniqueness, thus testing the model used for this study in different contexts would be expected to yield valuable insights. Moreover, the findings of this study have been discussed in light of resource-based theory, attributing the differences in moderation outcomes to the type of collaboration partner, which is usually determined by the kind of targeted resources sought from collaboration. Future researchers are encouraged to re-assess this justification and view the outcomes from other theoretical perspectives.

\section{References}

Abernathy, W.J., \& Clark, K.B. 1993. Innovation: Mapping the winds of creative destruction. Research Policy, 22(2): 102-102.

DOI: https://doi.org/10.1016/0048-7333(93)90040-o

Aghina, W., Smet, A.D., \& Weerda, K. 2015. Agility: It rhymes with stability. McKinsey Quarterly, 51(4): 2-9.

Agrawal, P., Narain, R., \& Ullah, I. 2019. Analysis Of Barriers In Implementation Of Digital Transformation Of Supply Chain Using Interpretive Structural Modelling Approach. Journal of Modelling in Management, 15(1): 297-317.

DOI: https://doi.org/10.1108/jm2-03-2019-0066

Ancona, D.G., Goodman, P.S., Lawrence, B.S., \& Tushman, M.L. 2001. Time: A new research lens. Academy of Management Review, 26(4): 645-663. DOI: https://doi.org/10.5465/amr.2001.5393903

Andriole, S.J. 2017. Five Myths About Digital Transformation. MIT Sloan Management Review, 58(3): 20-22.

Arranz, N., \& de Arroyabe, J.C.F. 2008. The Choice Of Partners In R\&D Cooperation: An empirical analysis of Spanish firms. Technovation, 28(1-2): 88-100 DOI:

https://doi.org/10.1016/j.technovation.2007.07.006

Barnes, D., Hinton, M., \& Mieczkowska, S. 2004. ECommerce In The Old Economy: Three case study examples. Journal of Manufacturing Technology Management, 15(7): 607-617.

DOI: https://doi.org/10.1108/17410380410555853

Beamon, B.M. 1999. Measuring Supply Chain Performance. International Journal of Operations \& Production Management, 19(3): 275-292.

DOI: https://doi.org/10.1108/01443579910249714

Becker, W., \& Dietz, J. 2004. R\&D Cooperation And Innovation Activities Of Firms: Evidence For The German Manufacturing Industry. Research Policy, 33(2): 209-223.

DOI: https://doi.org/10.1016/j.respol.2003.07.003
Birkinshaw, J., \& Gibson, C. 2004. Building Ambidexterity Into An Organization. MIT Sloan Management Review, 45(4): 47-55.

Burchardt, C., \& Maisch, B. 2019. Digitalization Needs A Cultural Change: Examples Of Applying Agility And Open Innovation To Drive The Digital Transformation. Procedia CIRP, 84:112-117.

DOI: https://doi.org/10.1016/j.procir.2019.05.009

Büyüközkan, G., \& Göçer, F. 2018. Digital Supply Chain: Literature review and a proposed framework for future research. Computers in Industry, 97:157-177. DOi: https://doi.org/10.1016/j.compind.2018.02.010

Calatayud, A., Mangan, J., \& Christopher, M. 2019. The Self-Thinking Supply Chain. Supply Chain Management: An International Journal, 24(1): 22-38.

DOI: https://doi.org/10.1108/scm-03-2018-0136

Castorena, D.G., \& Monroy, B.C.R. 2020. Ambidexterity In The Supply Chain: Studying the apparel industry. International Journal of Agile Systems and Management, 13(2): 130.

DOI: https://doi.org/10.1504/IJASM.2020.107904

Chanias, S. 2017. Mastering Digital Transformation: the path of a financial services provider towards a digital transformation strategy. 16-31. Conference: 25th European Conference on Information Systems (ECIS 2017)At: Guimarães, Portugal

Chesbrough, H.W. 2003. A Better Way To Innovate. Harvard Business Review, 81(7): 12-13.

Desmet, D., Duncan, E., Scanlan, J., \& SingerSix, M. 2015. Building Blocks For Creating A Highperforming Digital Enterprise. McKinsey Quarterly.

Accessed

online: https://www.mckinsey.com/business-

functions/organization/our-insights/six-building-

blocks-for-creating-a-high-performing-digitalenterprise

Du, W., Pan, S.L., \& Huang, J. 2016. How A Latecomer Company Used IT To Redeploy Slack Resources. MIS Quarterly Executive, 15(3): 195-213.

Accessed https://aisel.aisnet.org/misqe/vol15/iss3/3

online:

Duncan, R.B. 1976. The Ambidextrous Organization: Designing dual structures for innovation. The Management of Organization, 1(1): 167-188.

Earley, S. 2014. The Digital Transformation: Staying competitive. IT Professional, 16(2): 58-60.

DOI: https://doi.org/10.1109/mitp.2014.24

Evolving Innovation. 2019. JapanGov - The Government of Japan.

Accessed online: http://www.japan.go.jp/investment/evolving_innova tion.html

Fritsch, M., \& Lukas, R. 2001. Who Cooperates On R\&D? Research Policy, 30(2): 297-312. DOI: https://doi.org/10.1016/S0048-7333(99)00115-8 


\section{The Interplay of Digital Transformation and Collaborative Innovation on Supply Chain Ambidexterity Sara Abdalla, Koichi Nakagawa}

Gassmann, O. 2006. Opening Up The Innovation Process: Towards an agenda. $R \& D$ Management, 36(3): 223-228.

DOI:

9310.2006.00437.x

https://doi.org/10.1111/j.1467-

Gassmann, O., \& Enkel, E. 2004. Towards A Theory Of Open Innovation: Three core process archetypes. In: Proceedings of the $R \& D$ Management Conference (RADMA). Sessimbra.

Gibson, C.B., \& Birkinshaw, J. 2004. The Antecedents, Consequences, And Mediating Role Of Organizational Ambidexterity. Academy of Management Journal, 47(2): 209-226.

DOI: https://doi.org/10.2307/20159573

Günther, W.A., Mehrizi, M.H.R., Huysman, M., \& Feldberg, F. 2017. Debating Big Data: A literature review on realizing value from big data. The Journal of Strategic Information Systems, 26(3): 191-209.

DOI: https://doi.org/10.1016/j.jsis.2017.07.003

Gust, G., Neumann, D., Flath, C.M., Brandt, T., \& Ströhle, P. 2017. How A Traditional Company Seeded New Analytics Capabilities. MIS Quarterly Executive, 16(3): 215-230.

Hair, J.F., Risher, J.J., Sarstedt, M., \& Ringle, C.M. 2019. When To Use And How To Report The Results Of PLSSEM. European Business Review, 31(1): 2-24.

DOI: https://doi.org/10.1108/EBR-11-2018-0203

Hannan, M.T., \& Freeman, J. 1977. The Population Ecology Of Organizations. American Journal of Sociology, 82(5): 929-964.

DOI: https://doi.org/10.1086/226424

Hansen, R., \& Sia, S.K. 2015. Hummel's Digital Transformation Toward Omnichannel Retailing: Key Lessons Learned. MIS Quarterly Executive, 14(2): 5166.

Heide, J.B., \& John, G. 1990. Alliances In Industrial Purchasing: The determinants of joint action in buyer-supplier relationships. Journal of Marketing Research, 27(1): 24-36.

DOI: https://doi.org/10.1177/002224379002700103

Heilig, L., Schwarze, S., \& Voß, S. 2017. An Analysis Of Digital Transformation In The History And Future Of Modern Ports. In: Proceedings of the 50th Hawaii International Conference on System Sciences.

DOI: https://doi.org/10.24251/hicss.2017.160

Henseler, J., Ringle, C.M., \& Sarstedt, M. 2015. A New Criterion For Assessing Discriminant Validity In Variance-Based Structural Equation Modeling. Journal of the Academy of Marketing Science, 43(1): $115-135$.

DOI: https://doi.org/10.1007/s11747-014-0403-8

Hess, T., Matt, C., Benlian, A., \& Wiesböck, F. 2016. Options For Formulating A Digital Transformation Strategy. MIS Quarterly Executive, 15(2): 123-139. DOI: https://doi.org/10.4324/9780429286797-7
Horlacher, A., Klarner, P., \& Hess, T. 2016. Crossing Boundaries: Organization design parameters surrounding CDOs and their digital transformation activities. In: Americas Conference of Information Systems, San Diego, CA.

Huang, J., Henfridsson, O., Liu, M.J., \& Newell, S. 2017. Growing On Steroids: Rapidly scaling the user base of digital ventures through digital innovation. MIS Quarterly, 41(1): 301-314.

DOI: https://doi.org/10.25300/misq/2017/41.1.16

Hyll, W., \& Pippel, G. 2016. Types Of Cooperation Partners As Determinants Of Innovation Failures. Technology Analysis \& Strategic Management, 28(4): 462-476.

DOI: https://doi.org/10.1080/09537325.2015.1100292

Im, G., \& Rai, A. 2008. Knowledge Sharing Ambidexterity In Long-Term Interorganizational Relationships. Management Science, 54(7): 1281-1296.

DOI: https://doi.org/10.1287/mnsc.1080.0902

Jonsson, P., Kjellsdotter, L., \& Rudberg, M. 2007. Applying Advanced Planning Systems For Supply Chain Planning: Three case studies. International Journal of Physical Distribution and Logistics Management, 37(10): 816-834.

DOI: https://doi.org/10.1108/09600030710848932

Kane, G.C. 2014. The American Red Cross: Adding digital volunteers to its ranks.

MIT Sloan Management Review, 55(4): 1-6.

Karagiannaki, A., Vergados, G., \& Fouskas, K. 2017. The Impact Of Digital Transformation In The Financial Services Industry: Insights from an open innovation initiative in fintech in Greece. Mediterranean Conference on Information Systems (MCIS).

Karimi, J., \& Walter, Z. 2015. The Role Of Dynamic Capabilities In Responding To Digital Disruption: A factor-based study of the newspaper industry. Journal of Management Information Systems, 32(1): 39-81.

DOI: https://doi.org/10.1080/07421222.2015.1029380

Ketchen, D.J., \& Hult, G.T.M. 2007. Toward Greater Integration Of Insights From Organization Theory And Supply Chain Management. Journal of Operations Management, 25(2): 455-458.

https://doi.org/10.1016/j.jom.2006.05.001

Kim, D., Cavusgil, S.T., \& Calantone, R.J. 2006. Information System Innovations And Supply Chain Management: Channel Relationships and Firm Performance. Journal of the Academy of Marketing Science, 34(1): 40-54.

DOI: https://doi.org/10.1177/0092070305281619

Kock, N. 2015. Common Method Bias in PLS-SEM: A Full Collinearity Assessment Approach. International Journal of E-Collaboration, 11(4): 1-10.

DOI: https://doi.org/10.4018/ijec.2015100101 


\section{The Interplay of Digital Transformation and Collaborative Innovation on Supply Chain Ambidexterity Sara Abdalla, Koichi Nakagawa}

Kwak, D.W., Seo, Y.J., \& Mason, R. 2018. Investigating The Relationship Between Supply Chain Innovation, Risk Management Capabilities And Competitive Advantage In Global Supply Chains. International Journal of Operations \& Production Management, 38(1): 2-21.

DOI: https://doi.org/10.1108/IJOPM-06-2015-0390

Lamming, R. 1993. Beyond Partnership: Strategies for innovation and lean supply. Prentice Hall.

Laursen, K., \& Salter, A. 2006. Open For Innovation: The role of openness in explaining innovation performance among UK manufacturing firms. Strategic Management Journal, 27(2): 131-150.

DOI: https://doi.org/10.1002/smj.507

Lee, S.M., \& Rha, J.S. 2016. Ambidextrous Supply Chain As A Dynamic Capability: Building a resilient supply chain. Management Decision, 54(1): 2-23. DOI: https://doi.org/10.1108/md-12-2014-0674

Li, L., Su, F., Zhang, W., \& Mao, J.Y. 2018. Digital Transformation By SME Entrepreneurs: A capability perspective. Information Systems Journal, 28(6): 11291157.

DOI: https://doi.org/10.1111/isj.12153

Lichtenthaler, U. 2008. Open Innovation In Practice: An analysis of strategic approaches to technology transactions. IEEE Transactions on Engineering Management, 55(1): 148-157.

DOI: https://doi.org/10.1109/tem.2007.912932

Loebbecke, C., \& Picot, A. 2015. Reflections On Societal And Business Model Transformation Arising From Digitization And Big Data Analytics: A research agenda. The Journal of Strategic Information Systems, 24(3): 149-157.

DOI: https://doi.org/10.1016/j.jsis.2015.08.002

Maedche, A. 2016. Interview With Michael Nilles On "What Makes Leaders Successful In The Age Of The Digital Transformation?" Business \& Information Systems Engineering, 58(4): 287-289.

DOI: https://doi.org/10.1007/s12599-016-0437-1

Miotti, L., \& Sachwald, F. 2003. Co-Operative R\&D: Why And With Whom?: An integrated framework of analysis. Research Policy, 32(8): 1481-1499. DOI: https://doi.org/10.1016/s0048-7333(02)00159-2

Monsef, S., \& Ismail, W.K.W. 2012. The Impact Of Open Innovation In New Product Development Process. International Journal of Fundamental Psychology \& Social Sciences, 2(1): 7-12.

Najafi-Tavani, S., Najafi-Tavani, Z., Naudé, P., Oghazi, P., \& Zeynaloo, E. 2018. How Collaborative Innovation Networks Affect New Product Performance: Product innovation capability, process innovation capability, and absorptive capacity. Industrial Marketing Management, 73: 193-205.

DOI:

https://doi.org/10.1016/j.indmarman.2018.02.009

O’Reilly III, C.A., \& Tushman, M.L. 2013. Organizational Ambidexterity: Past, present, and future. Academy of Management Perspectives, 27(4): 324-338.

DOI: https://doi.org/10.5465/amp.2013.0025
Oxley, J.E., \& Sampson, R.C. 2004. The Scope And Governance Of International R\&D Alliances. Strategic Management Journal, 25(8-9): 723-749.

DOI: https://doi.org/10.1002/smj.391

Pagani, M. 2013. Digital Business Strategy and Value Creation: Framing the Dynamic Cycle of Control Points. MIS Quarterly, 37(2): 617-632. DOI: https: / / doi.org/10.25300/misq/2013/37.2.13

Park, N.K., Mezias, J.M., \& Song, J. 2004. A ResourceBased View Of Strategic Alliances And Firm Value In The Electronic Marketplace. Journal of Management, 30(1): 7-27.

DOI: https://doi.org/10.1016/j.jm.2002.11.001

Pu, X., Wang, Z., \& Chan, F.T.S. 2020. Leveraging Open E-Logistic Standards To Achieve Ambidexterity In Supply Chain. Journal of Computer Information Systems, 60(4): 347-358.

DOI: https://doi.org/10.1080/08874417.2018.1488543

Raisch, S., Birkinshaw, J., Probst, G., \& Tushman, M.L. 2009. Organizational Ambidexterity: Balancing Exploitation and Exploration for Sustained Performance. Organization Science, 20(4): 685-695. DOI: https://doi.org/10.1287/orsc.1090.0428

Ringle, C.M., Wende, S., \& Will, A. 2005. SmartPLS (3.8.2) [Computer software].

Accessed online: https://www.smartpls.com/

RStudio Team. 2020.

Accessed online: https://www.R-project.org/.

Schulze, P., Heinemann, F., \& Abedin, A. 2008. Balancing Exploitation And Exploration. Academy of Management Proceedings: 2008(1), 1-6.

Selander, L., \& Jarvenpaa, S.L. 2016. Digital Action Repertoires And Transforming A Social Movement Organization. MIS Quarterly, 40(2): 331-352.

DOI: https://doi.org/10.25300/misq/2016/40.2.03

Setia, P., Venkatesh, V., \& Joglekar, S. 2013. Leveraging Digital Technologies: How Information Quality Leads to Localized Capabilities and Customer Service Performance. MIS Quarterly, 37(2): 565-590.

DOI: https://doi.org/10.25300/misq/2013/37.2.11

Sezen, B. 2008. Relative Effects Of Design, Integration And Information Sharing On Supply Chain Performance. Supply Chain Management: An International Journal, 13(3): 233-240.

DOI: https://doi.org/10.1108/13598540810871271

Stentoft, J., \& Rajkumar, C. 2018. Does Supply Chain Innovation Pay Off? In A. C. Moreira, L. M. D. F. Ferreira, \& R. A. Zimmermann (Eds.), Innovation and Supply Chain Management. 237-256. Springer International Publishing.

DOI: https://doi.org/10.1007/978-3-319-74304-2_11

Svahn, F., Mathiassen, L., \& Lindgren, R. 2017. Embracing Digital Innovation In Incumbent Firms: How Volvo Cars Managed Competing Concerns. MIS Quarterly, 41(1): 239-254.

DOI: https://doi.org/10.25300/misq/2017/41.1.12 


\section{The Interplay of Digital Transformation and Collaborative Innovation on Supply Chain Ambidexterity Sara Abdalla, Koichi Nakagawa}

Swink, M. 2006. Building Collaborative Innovation Capability. Research-Technology Management, 49(2): 37-47.

DOI:

https://doi.org/10.1080/08956308.2006.11657367

Tether, B.S. 2002. Who Co-Operates For Innovation, And Why: An empirical analysis. Research Policy, 31(6): 947-967.

DOI: https://doi.org/10.1016/s0048-7333(01)00172-x

Vial, G. 2019. Understanding Digital Transformation: A review and a research agenda. The Journal of Strategic Information Systems, 28(2): 118-144.

DOI: https://doi.org/10.1016/j.jsis.2019.01.003

World Intellectual Property Indicators. 2019. Accessed

online: https://www.wipo.int/publications/en/details.jsp?id $=4464$

Yoo, Y., Henfridsson, O., \& Lyytinen, K. 2010. Research Commentary: the new organizing logic of digital innovation: An agenda for information systems research. Information Systems Research, 21(4): 724735.

DOI: https://doi.org/10.1287/isre.1100.0322

Yoon, S.N., Lee, D., \& Schniederjans, M. 2016. Effects of Innovation Leadership and Supply Chain Innovation on Supply Chain Efficiency: Focusing on hospital size. Technological Forecasting and Social Change, 113(PB): 412-421.

DOI: https://doi.org/10.1016/j.techfore.2016.07.015

Zhou, K.Z., \& Li, C.B. 2012. How Knowledge Affects Radical Innovation: Knowledge base, market knowledge acquisition, and internal knowledge sharing. Strategic Management Journal, 33(9): 10901102.

DOI: https://doi.org/10.1002/smj.1959

\section{About the Authors}

Sara Abdalla is a Management and Business Administration Lecturer at the University of Khartoum, Sudan, where she received her B.Sc. in Business Administration and MBA degree. She won the Japanese Government (MEXT) Scholarship in 2018 and joined the Graduate School of Economics at Osaka University. After a one-year research studentship, she is currently conducting her Ph.D. in Business Administration. Her research is mainly situated in the field of operations management, with a focus on innovation and technology. She has been awarded the Best Student Paper Award at the ITMC conference in September 2019 and was part of the winning team of the Hult Prize Osaka University OnCampus Program in December 2019. Her recent contributions have been presented at the 32nd EBES conference in August 2020 and the ISPIM Connects Global conference in December 2020.

Koichi Nakagawa is the president of Yasashii Business Lab, Japan. He received a $\mathrm{PhD}$ in Economics from The University of Tokyo. After working on innovation education as an Associate Professor at the Graduate School of Economics, Osaka University, he started his own business. Now he studies and practice as a consultant the management of innovation and corporate strategy. Also, he tries to provide academic knowledge on the YouTube.

Citation: Abdalla, S., Nakagawa, K. 2021. The Interplay of Digita Transformation and Collaborative Innovation on Supply Chain Ambidexterity. Technology Innovation Management Review, 11(3): 4556. http://doi.org/10.22215/timreview/ 1428 